\title{
Differences in body compositions, growth and food intakes between mice which have been selected for a small and large body size
}

\author{
BY GARRY J. RUCKLIDGE \\ Rowett Research Institute, Greenburn Road, Bucksburn, Aberdeen AB2 9SB
}

(Received 11 March 1981 - Accepted 19 May 1981)

1. Q-strain mice selected for high (QLF) or low (QSC) body-weight at 6 weeks of age were compared with respect to their body-weight increases, gross body compositions and food intakes.

2. DNA, RNA, protein and hydroxyproline contents were measured.

3. QLF animals were larger at all stages of development but ate more food and gained more body-weight per unit food intake with an appars:ntly improved efficiency of utilization compared with QSC mice.

4. The efficiency of deposition of dietary energy in Q-strain mice was found to be significantly lower than that of other growing mammals receiving similar energy intakes.

5. Body water, protein and fat of both strains were similar at birth and at $\mathbf{4 2} \mathrm{d}$ of age but the contribution of fat to body-weight in the preweaning phase was greater for QLF while QSC accreted more fat per l'nit weight gain in the postweaning period.

6. An increase in cell number made a greater contribution to the growth post partum of the QLF mice, but by $42 \mathrm{~d}$ of age little difference between the number of cells per unit weight in the two strains was evident.

7. Despite increases in RNA concentrations at all stages of development, of QLF mice compared with QSC, measurements of body composition do not indicate any accompanying increases of protein concentration in these animals.

From a base population of random-bred Q-strain mice, genetic selection has been performed on the basis of large or small body-weight at 6 weeks of age (Falconer, 1973). Mice other than Q-strai: have been selected on the basis of differences in their rates of growth during either the pre-or postweaning period (Brown \& Frahm, 1975; Kownacki et al. 1975). However, selection for large size at 6 weeks produces a correlated response of rapid growth before anc. after weaning. It is therefore reasonable to regard information about animals selected under one regimen as having some relevance to the corresponding line from the other set, e.g. small 6 week body-weight animals compared with animals with a slow rate of growth during the postweaning period.

In order to define differences in body compositions between mice selected for fast or slow growth, as opposed to those selected for large or small body size, previous studies have concentrated largely on comparisons of 'cell sizes' and cell numbers in individual organs (Robinson \& Bradford, 1969; Eisen et al. 1978) and in particular the skeletal muscle from these mice has been well characterized (Luff \& Goldspink, 1967; Ezekwe \& Martin, 1975). To estimate efficiency of food utilization, the ratio, weight gain:food consumed, (FCR) food intake has to be measured. This has been done by Brown \& Frahm (1975) and Brown et al. (1977) who found that the FCR was increased by selection for rapid postweaning growth. Kownacki et al. (1975) arid Kownacki \& Keller (1978) have shown that the basal metabolic rate is lower in mice selected for rapid growth compared to unselected controls.

Deoxyribonucleic acid (DNA), ribonucleic acid (RNA) and protein contents of brain, liver, kidney, heart, skeletal muscle, spleen and lung have been compared in Q-strain mice selected for large and small body size (Priestley \& Robertson, 1973; Falconer et al. 1978). Skeletal muscle has been shown to contain more fibres of an increased length in the Q-strain mice selected for large body size (Hanrahan et al. 1973). Some results regarding food intake of Q-strain mice have been published (Falconer, 1977) but these do not illustrate differences between selected lines in terms of efficiency of food utilization. 
Table 1. Diet composition $(\mathrm{g} / \mathrm{kg})$

\begin{tabular}{|c|c|}
\hline \multicolumn{2}{|l|}{ Ingredient } \\
\hline Casein & $223 \cdot 0$ \\
\hline Maize starch & $443 \cdot 0$ \\
\hline Glucose & $112 \cdot 0$ \\
\hline Salt mixture* & $60 \cdot 0$ \\
\hline Cellulose & $110 \cdot 0$ \\
\hline Maize oil & $50 \cdot 0$ \\
\hline Vitamin mixture* & $2 \cdot 0$ \\
\hline \multicolumn{2}{|l|}{ Chemical composition } \\
\hline Total nitrogen & $31 \cdot 7$ \\
\hline Fat & $47 \cdot 1$ \\
\hline Dry matter & 915 \\
\hline Gross energy (MJ/kg dry matter) & 18.88 \\
\hline Apparently digestible $\mathbf{N}$ & $28 \cdot 2$ \\
\hline Apparently digestible energy ( $\mathrm{MJ} / \mathrm{kg}$ dry matter) & $17 \cdot 18$ \\
\hline
\end{tabular}

* Miller \& Bender (1955).

There is little information about the contribution of body fat to differences in efficiency defined as gain in weight per unit food intake between the selected lines of Q-strain mice and in general the chemical composition of the whole body of these mice has not been well defined, particularly at an early age. It seemed desirable to examine the whole-body composition of the different lines of Q-strain mice at different stages of development from birth to $42 \mathrm{~d}$ of age. These findings and differences in the efficiencies of utilization of food between large and small selected Q-strain mice are reported in the present paper.

\section{MATERIALS AND METHODS}

Experimental animals were obtained from the Unit of Animal Genetics, Edinburgh. The breeding stock of large mice was designated QLF (Q-strain, large line (L), replicate (F)) and that of the small mice QSC (Q-strain, small line (S), replicate (C); Falconer, 1973). The stocks of the Unit of Animal Genetics had been maintained with normal precautions to prevent infection; on arrival at this Institute they were tested and found free of Toxoplasma.

Once the female was confirmed to be pregnant, the male was removed before parturition to prevent post-partum mating. Litters were culled to eight pups on the day of birth to standardize litter size. The pups were weighed daily from birth until $19 \mathrm{~d}$ when they were removed and the mother mated again.

At $19 \mathrm{~d}$ post partum, two mice (one male, one female) were placed in a metabolism cage (Rucklidge \& McKenzie, 1980) and their combined intake of a powdered, semi-synthetic diet, the composition of which is given in Table 1, was measured. The room temperature was held at $25^{\circ}$ and the mice had free access to water. Urine and faeces were collected daily and their nitrogen contents estimated by the Kjeldahl method as modified by Davidson $e t$ al. (1970). The remaining mice in the litter were killed at $19 \mathrm{~d}$ post partum. At $42 \mathrm{~d}$ of age the mice used in the metabolism trial were weighed and killed. All mice whether killed at 19 or $42 \mathrm{~d}$ were treated similarly. The abdominal cavity was opened, gut contents were flushed with distilled water to remove digesta, and the digesta-free carcass was reweighed, frozen and freeze-dried. The dried carcass was weighed and finely ground and representative homogeneous samples were removed for the various estimations, each of which was performed in duplicate. 


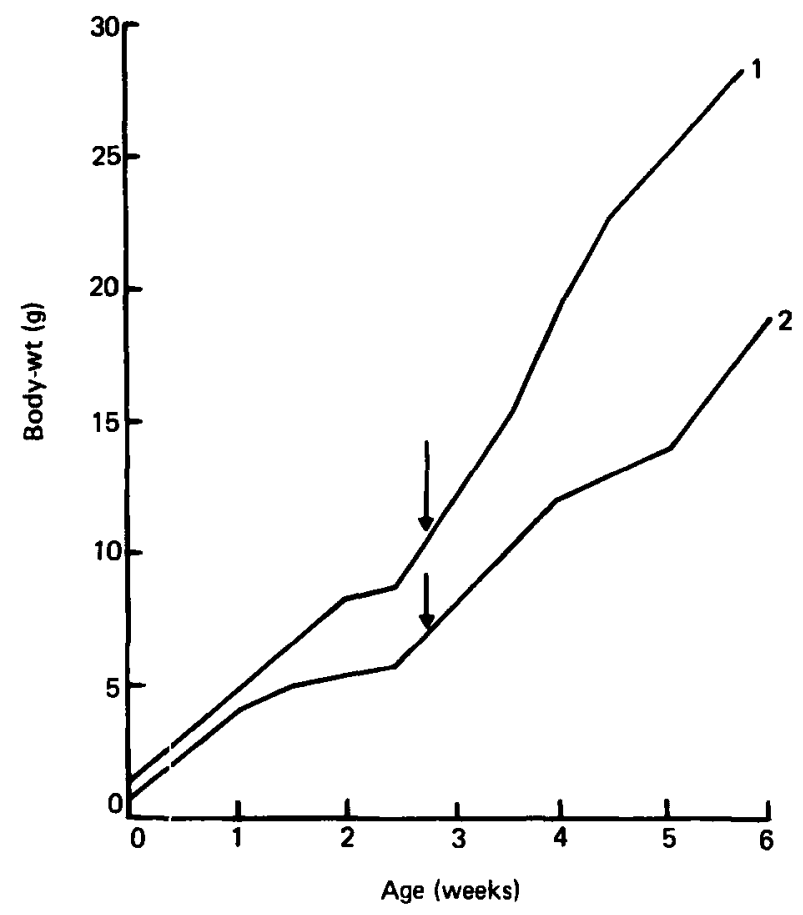

Fig. 1. Growth curves of selected mice from birth to 6 weeks of age. (1) Large line (QLF) mice, (2) small line (QSC) mice, $19 \mathrm{~d}$ of age (weaning).

Body protein was measured by the Kjeldahl method as described previously (Davidson et al. 1970). Fat was estimated by chloroform-methanol extraction (Atkinson et al. 1972). Ash was measured by cornplete combustion of the dried carcass.

RNA and DNA were measured by a modification of the Schmidt-Thannhauser method as recommended by Munro \& Fleck (1969). A sample of the dried carcass was hydrolysed for $18 \mathrm{~h}$ in $5.7 \mathrm{M}$-hydrochloric acid at $108^{\circ}$ and the hydroxyproline content of the hydrolysate was estimated by the method of Firschein \& Shill (1966).

\section{RESULTS}

The body-weights of QLF and QSC mice were measured daily from birth until $42 \mathrm{~d}$ and the growth curves are shown in Fig. 1. At all ages QLF mice were heavier than QSC $(P<0.001$ at birth, 19 ard $42 \mathrm{~d}$; Table 2$)$.

The compositions of the QLF and QSC mice at birth, 19 and $42 \mathrm{~d}$ were measured and are shown in Table 2 . The concentration ( $\mathrm{g} / \mathrm{kg}$ body-weight) of body water in large mice was lower $(P<0.05)$ than in small mice at $19 \mathrm{~d}$ but was not different at birth or $42 \mathrm{~d}$. There were no differences between the lines in concentration body protein or ash at 19 or $42 \mathrm{~d}$ of age. The concentration of body fat was higher in QLF mice at $19 \mathrm{~d}(P<0.05)$ but at $42 \mathrm{~d}$ was similar to that of the QSC mice. Estimates of body composition of the mouse pups at birth are included in Tables 2 and 4 ; these were made on a single pooled sample. The composition of weight gains between birth and weaning and between weaning and $42 \mathrm{~d}$ for both lines are shown in Table 3.

As one might expect from the values for body composition in Table 2, the contribution 


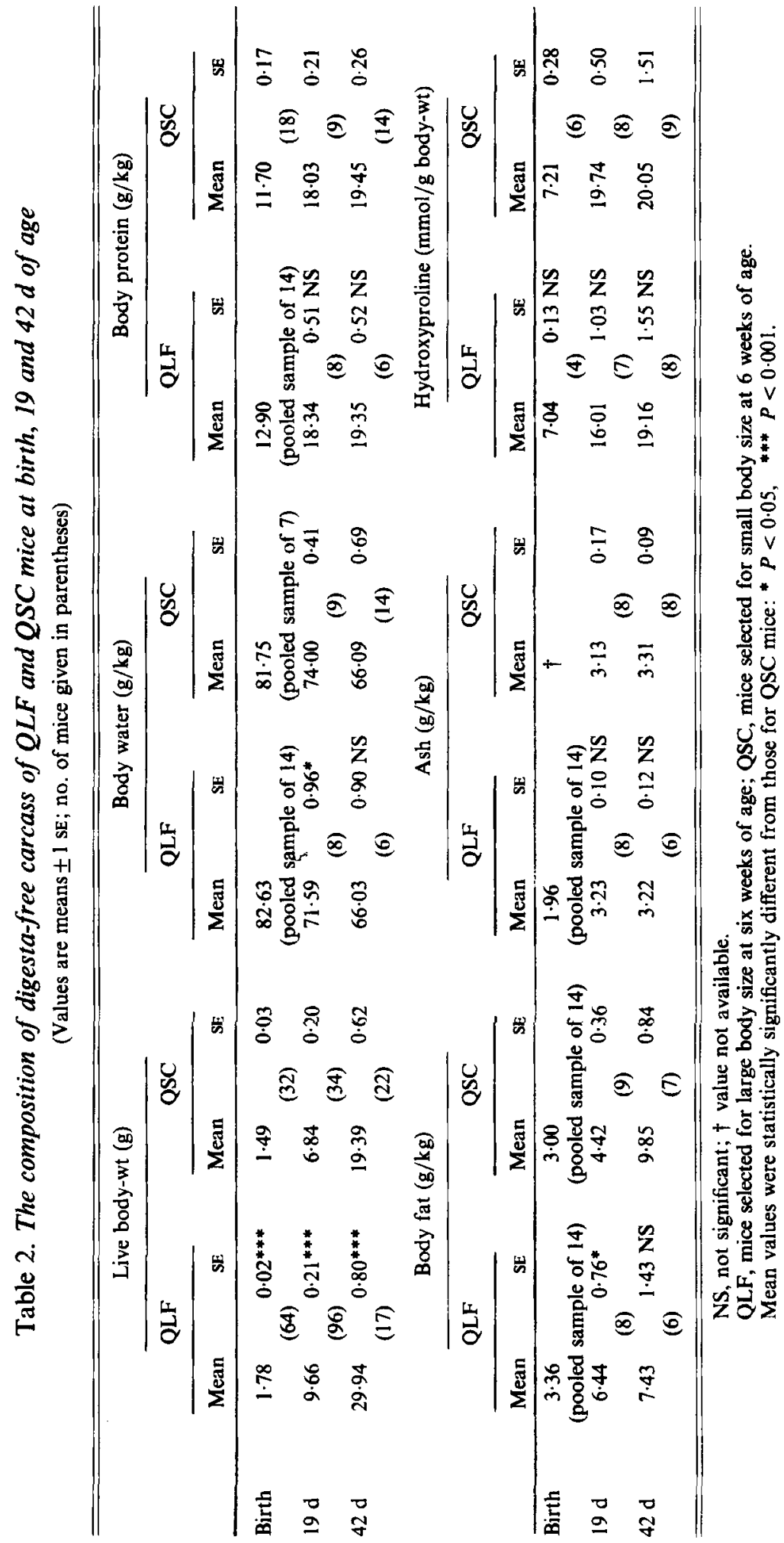


Table 3. The composition of weight gains (protein, fat, water, ash, DNA and RNA) between birth and weaning and between weaning and $42 d$ for $Q L F$ and QSC mice

\begin{tabular}{|c|c|c|c|c|c|c|c|c|}
\hline \multirow{3}{*}{ Gain from ... } & \multicolumn{4}{|c|}{ QLF } & \multicolumn{4}{|c|}{ QSC } \\
\hline & \multicolumn{2}{|c|}{$\begin{array}{c}\text { 3irth } \\
\text { to weaning }\end{array}$} & \multicolumn{2}{|c|}{$\begin{array}{l}\text { Weaning } \\
\text { to } 42 \mathrm{~d}\end{array}$} & \multicolumn{2}{|c|}{$\begin{array}{c}\text { Birth } \\
\text { to weaning }\end{array}$} & \multicolumn{2}{|c|}{$\begin{array}{l}\text { Weaning } \\
\text { to } 42 \mathrm{~d}\end{array}$} \\
\hline & Total & $\%$ of gain & Total & $\%$ of gain & Total & $\%$ of gain & Total & $\%$ of gain \\
\hline $\begin{array}{l}\text { Body-wt (g) } \\
\text { Body protein (g) } \\
\text { Body fat (g) } \\
\text { Body water (g) } \\
\text { Ash (g) } \\
\text { DNA (mg) } \\
\text { RNA (mg) }\end{array}$ & $\begin{array}{c}7.88 \\
1.55 \\
0.56 \\
5.44 \\
0.28 \\
5.93 \\
40.52\end{array}$ & $\begin{array}{l}100 \\
19 \cdot 63 \\
7 \cdot 11 \\
69 \cdot 10 \\
3 \cdot 52 \\
0 \cdot 075 \\
0 \cdot 51\end{array}$ & $\begin{array}{r}20.28 \\
4.01 \\
1.60 \\
13.45 \\
0.65 \\
34.02 \\
165.80\end{array}$ & $\begin{array}{c}100 \\
19 \cdot 80 \\
7 \cdot 89 \\
66 \cdot 33 \\
3 \cdot 21 \\
0 \cdot 17 \\
0.82\end{array}$ & $\begin{array}{r}5.35 \\
1.00 \\
0.26 \\
3.84 \\
\text { ND } \\
3.50 \\
13.02\end{array}$ & $\begin{array}{l}100 \\
18 \cdot 69 \\
4 \cdot 82 \\
71 \cdot 78 \\
\mathrm{ND} \\
0 \cdot 065 \\
0 \cdot 24\end{array}$ & $\begin{array}{r}12.55 \\
2.59 \\
1.61 \\
7.75 \\
0.43 \\
19.37 \\
73.41\end{array}$ & $\begin{array}{l}100 \\
20.66 \\
12.79 \\
61.78 \\
3.41 \\
0.15 \\
0.58\end{array}$ \\
\hline
\end{tabular}

QLF, mice selected for large body size at 6 weeks of age; QSC, mice selected for small body size at 6 weeks of age; ND, not determined.

Table 4. The concentrations of DNA, RNA and protein, and protein:DNA, RNA:DNA and protein: $R N A$ in digesta-jree carcases of $Q L F$ and $Q S C$ mice at birth, 19 and $42 d$ of age

(Values are means \pm 1 SE; no. of mice in parentheses)

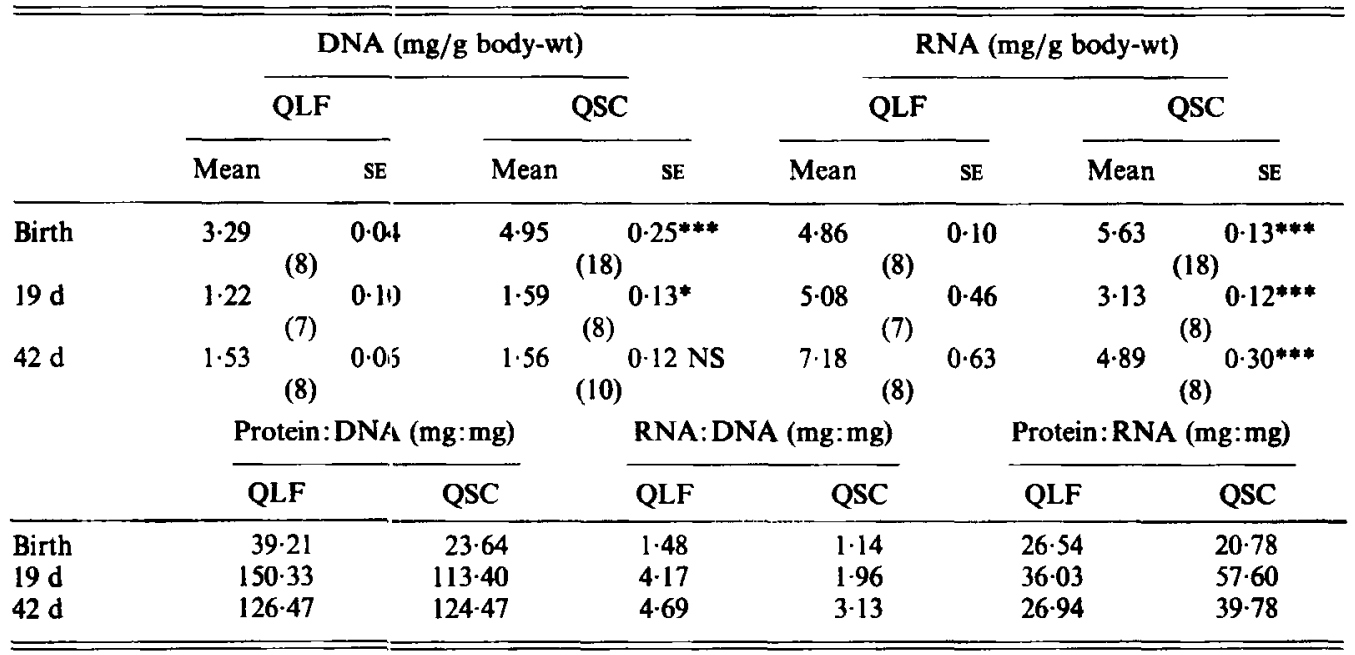

NS, not significant; QLF, m ce selected for large body size at 6 weeks of age; QSC, mice selected for small body size at 6 weeks of age.

Mean values were statistically different from those for QLF mice: $P<0.05, * * * P<0.001$.

of protein to the weight gain was similar in the two lines at the same stage of development (Table 3). In the QLF mice however, body fat contributed more to weight gains before weaning than in the QSC mice whereas after weaning it contributed more in the QSC mice. Differences in body fat bitween lines at $19 \mathrm{~d}$ appeared to be made at the expense of body water rather than body frotein (Table 2 ).

The DNA concentration ( $\mathrm{mg} / \mathrm{g}$ body-weight) in the QLF animals was significantly less at birth $(P<0.001)$ and at $19 \mathrm{~d}$ of age $(P<0.05)$ than in the small animals (Table 4). As 

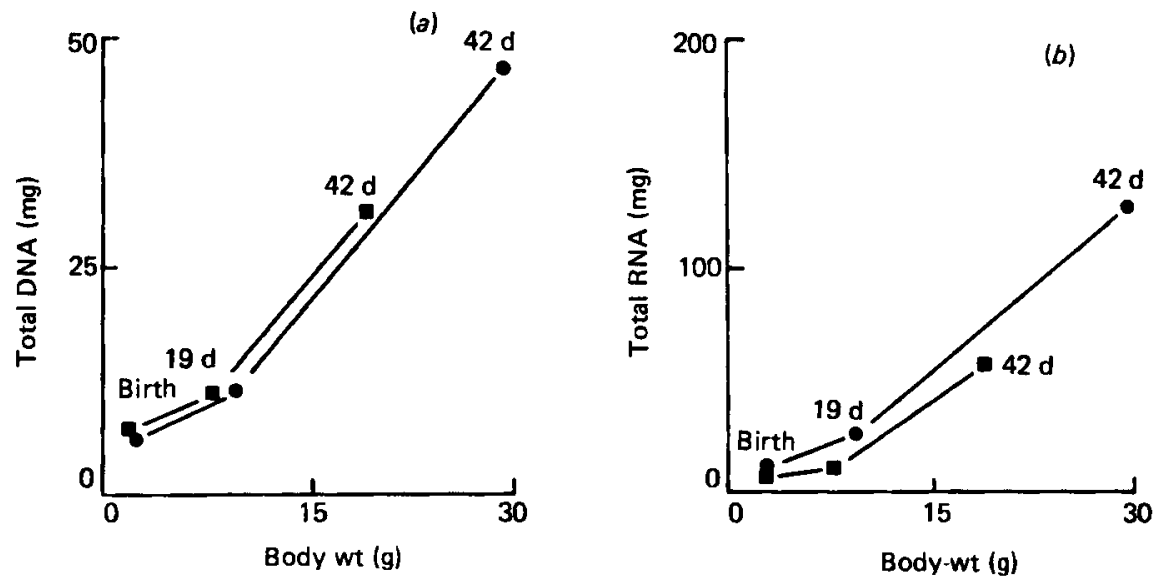

Fig. 2. The rate of accretion of total (a) DNA and (b) RNA with respect to body-weight. Slope of line of best fit:DNA for QLF mice (O) $1.33 \pm 0.20(\mathrm{mg} / \mathrm{g}$ body-wt) and for QSC mice ( 1 ) $1.47 \pm 0.20$ $(\mathrm{mg} / \mathrm{g}$ body-wt); RNA for QLF mice (O) $7 \cdot 50 \pm 0.67(\mathrm{mg} / \mathrm{g}$ body-wt) and for QSC mice ( $\mathrm{G}$ ) 5.01 $\pm 0 \cdot 78$ ( $\mathrm{mg} / \mathrm{g}$ body-wt).

Table 5. Food intake, nitrogen excretion, weight gains and grass food efficiency of QSC and $Q L F$ mice between 19 and $42 d$ of age on the feeding trials

(Values are means \pm 1 SE for two mice per cage)

\begin{tabular}{|c|c|c|c|c|}
\hline \multirow[t]{2}{*}{ No. of pairs of mice... } & \multicolumn{2}{|c|}{$\frac{\text { QLF }}{6}$} & \multicolumn{2}{|c|}{$\underset{4}{\mathrm{QSC}}$} \\
\hline & Mean & SE & Mean & SE \\
\hline Food intake (g/mouse) & $107 \cdot 30$ & 2.90 & $84 \cdot 45$ & $3 \cdot 68^{* * *}$ \\
\hline Wt increase (g/mouse) & $17 \cdot 74$ & 0.59 & $10 \cdot 37$ & $1 \cdot 04^{* * *}$ \\
\hline $\begin{array}{l}\text { Gross food efficiency } \\
\text { (g food intake/g wt gain) }\end{array}$ & 6.06 & $0 \cdot 12$ & $8 \cdot 23$ & $0.64^{* *}$ \\
\hline $\begin{array}{l}\text { Urinary } \mathrm{N} \text { excretion } \\
(\% \text { of } \mathrm{N} \text { intake) }\end{array}$ & $\mathbf{7 4 . 7 2}$ & 2.55 & $75 \cdot 28$ & 3.26 NS \\
\hline $\begin{array}{l}\text { Faecal } N \text { excretion } \\
(\% \text { of } N \text { intake) }\end{array}$ & 8.72 & 0.25 & $10 \cdot 42$ & $0.72^{*}$ \\
\hline
\end{tabular}

NS, not significant; QLF, mice selected for large body size at 6 weeks of age; QSC, mice selected for small body size at 6 weeks of age.

Mean values were statistically significantly different from those for QLF mice: ${ }^{*} P<0.05, * * P<0.01$, $* * * P<0.001$.

growth continued the DNA concentration declined in both lines. The rate of DNA accretion with respect to body-weight showed a similar pattern in the two lines Fig. 2(a). With respect to age however total DNA was lower in QLF animals at birth but was higher at 19 and $42 \mathrm{~d}$.

RNA concentration (mg/g body-weight) was higher $(P<0.01)$ for QSC animals at birth but was lower $(P<0.001)$ at 19 and $42 \mathrm{~d}$ (Table 4). With respect to body-weight rather than age the rate of accretion of RNA was not significantly different between lines but total RNA was higher in QLF animals at birth, 19 and $42 \mathrm{~d}$ (Fig. 2(b)).

The whole body hydroxyproline concentration which may be taken as an index of 
Table 6. The utilization of apparently digestible energy and apparently digestible nitrogen by QLF and QSC mice between 19 and 42 of age

(Values are mean $\pm 1 \mathrm{SE}$ )

\begin{tabular}{|c|c|c|c|c|}
\hline \multirow[t]{2}{*}{ No. of pairs of mice... } & \multicolumn{2}{|c|}{$\underset{6}{\text { QLF }}$} & \multicolumn{2}{|c|}{$\begin{array}{c}\text { QSC } \\
4\end{array}$} \\
\hline & Mean & SE & Mean & SE \\
\hline $\begin{array}{l}\text { Percentage digestible } \\
\text { energy deposited as } \\
\text { protein and fat } \dagger\end{array}$ & $7 \cdot 26$ & 0.75 & $8 \cdot 31$ & $0.54 \mathrm{NS}$ \\
\hline $\begin{array}{l}\text { Percentage digestible } \\
\text { energy deposited as fat }\end{array}$ & 2.79 & 0.72 & 4.86 & $0 \cdot 33^{*}$ \\
\hline $\begin{array}{l}\text { Percentage digestible } \\
\text { energy deposited as } \\
\text { protein }\end{array}$ & $4 \cdot 42$ & 0.27 & $3 \cdot 44$ & $0 \cdot 32^{*}$ \\
\hline $\begin{array}{l}\text { Percentage digestible } \\
\mathbf{N} \text { deposited as protein }\end{array}$ & $18 \cdot 09$ & $1 \cdot 15$ & $14 \cdot 08$ & $1 \cdot 30^{*}$ \\
\hline
\end{tabular}

NS, not significant.

QLF, mice selected for large body size at 6 weeks of age; QSC, mice selected for small body size at 6 weeks of age.

Mean values were statistically significantly different from those for QLF mice: ${ }^{*} P<0.05$.

$\dagger$ Assuming the heats of conbustion of body protein and fat to be 23.7 and $39.6 \mathrm{~kJ} / \mathrm{g}$ respectively.

collagenous protein concentration did not differ between the lines at any of the ages studied (Table 2).

Food intake, measured from 19 to $42 \mathrm{~d}$, was higher $(P<0.001)$ for the QLF mice. These mice also gained more in the same period $(P<0.001)$ (Table 5). The food intake on a per $\mathrm{g}$ body-weight increase basis was lower $(P<0.01)$ for the QLF animals. The mice in metabolism cages grew less well than those in the study of growth from birth to $42 \mathrm{~d}$ which were kept in standard mouse cages (weight gains (g) from 19-42 d in standard cages: QSC 12.55; QLF 20.28; corre:sponding values in metabolism cages: QSC 10.37; QLF 17.74).

Expressed as a percentage of $\mathrm{N}$ intake, urinary $\mathrm{N}$ did not differ between lines but faecal $\mathrm{N}$ was lower $(P<0.05)$. or QLF mice (Table 5).

The lines did not differ significantly in the percentage of apparently digestible energy which was deposited as the sum of protein and fat between 19 and $42 \mathrm{~d}$ (Table 6). However the partition of the retained energy was different between the strains. In terms of percentage digestible energy QLF animals deposited 2.79 as fat and 4.42 as protein while QSC mice deposited 4.86 as fat and 3.44 as protein between 19 and $42 \mathrm{~d}$ (Table 6). QLF animals deposited $18 \%$ of their digestible $\mathrm{N}$ as protein compared to $14 \%$ by QSC (Table 6 ).

\section{DISCUSSION}

The criteria for selection of Q-strain mice have been for an increased (QLF) or decreased (QSC) body-weight at $\mathbf{4 2} \mathrm{d}$. It is clear that selection for this trait has produced a correlated response in that the two lines of mice differ with respect to body-weight at all ages between birth and $42 \mathrm{~d}$. Although absolute weight gains were different, the relative rates of growth ( $g$ body-weight gain/g body-weight per $d$ ) were similar between 19 and $42 \mathrm{~d}(0.044$ and 0.042 for QLF and QSC respectively).

The experiments described in this paper set out to investigate whether selection: ( $a$ ) had altered the body composition, particularly with respect to changes in the rates of deposition 
of fat and protein and the efficiency with which food is deposited; $(b)$ had altered the cell size and number of cells in these animals.

As would be expected the QLF mice consumed more food than QSC mice but expressed per unit metabolic body-weight ( $\mathrm{kg}$ body-weight (W) ${ }^{0.75}$ ) QLF mice consumed a similar amount of food to QSC mice ( $\mathrm{g} / \mathrm{kg} \mathrm{W}^{0.75}$ per d; QLF 94.75; QSC 92.30). The efficiency with which food consumed was utilized for gain of body-weight was higher in QLF animals and this is consistent with the fact that protein deposition contributed a higher proportion of the energy deposition between 19 and $42 \mathrm{~d}$ in these animals. The apparent anomaly that body composition, with respect to protein, fat and water was little different at $\mathbf{4 2} \mathrm{d}$ of age is explained by the fact that between birth and weaning the QLF mice deposited proportionaltely more fat than the QSC line.

One of the most striking observations in the present work was the low efficiency with which dietary energy was deposited. In both lines, between 19 and $42 \mathrm{~d}$, approximately $8 \%$ of the total digestible energy was deposited as protein and fat, a value which is significantly lower than the gross efficiency of energy deposition in growing rats $(200 \mathrm{~g}$ rats deposit approximately $24 \%$ of their digestible energy; Pullar \& Webster, 1977) and pigs (30 kg pigs deposit approximately $30 \%$ of their digestible energy; Reeds et al. 1980) receiving a similar intake of energy per unit metabolic weight ( $1400 \mathrm{KJ} / \mathrm{kg} \mathrm{W}^{0.75}$ per d). A similarly low gross efficiency of energy deposition in mice both unselected and selected for rapid rates of growth can be calculated from the results of Brown et al. (1977) but this does not appear to be a universal finding in selected mice (Van der Wal et al. 1976). Although a contributory factor in this may be the high contribution of protein deposition to the weight gain, FCR ( $\mathrm{g}$ weight gain: $\mathrm{g}$ food intake) is also low.

Two questions arise from these observations. First, is the low efficiency of energy deposition associated with a high requirement of energy for maintenance and second, are the present findings characteristic of mice or due to selection for differences in weight gain? It is impossible to answer the first of these questions unequivocally using the results presented in the present paper because assumptions as to the efficiency with which energy above maintenance is deposited have to be made. However, adoption of the values for the partial energetic efficiencies of protein and fat deposition (Kielanowski, 1972) imply a maintenance heat production ( $\mathrm{kJ} / \mathrm{kg} \mathrm{W}^{0 \cdot 75}$ per d) of 1150 for QLF mice and 1250 for QSC mice, much higher than most estimates for other mammals (see Blaxter, 1972). Similar calculations from the results of Brown et al. (1977) also indicate a high maintenance heat production (WWL and ADGL mice selected for rapid rates of growth, and CL, control line, $950 \mathrm{~kJ} / \mathrm{kg} \mathrm{W}^{0.75}$ per d). This calculation is of course entirely dependent on the assumption that selection for high weight gains does not affect partial energetic efficiencies of either protein or fat deposition. Nevertheless there is some support for the view that maintenance heat production is elevated from measurements of basal metabolic rates (BMR) in mice selected for rapid rates of growth between 19 and $42 \mathrm{~d}$ (Kownacki \& Keller, 1978). Although their measurements were made using mice which were 5 months old, their results suggest a BMR (i.e. under fasting conditions) of approximately $600 \mathrm{~kJ} / \mathrm{kg} \mathrm{W}^{0} \cdot 75$ per $\mathrm{d}$.

Regarding the second of these questions, there are available in the literature two sets of measurements of BMR in mice which have not been specifically selected for rapid rates of growth (Benedict, 1938; Usinger, 1957). Both sets of measurements suggest values of between 250 and $300 \mathrm{~kJ} / \mathrm{kg} \mathrm{W}^{0.75}$ per $\mathrm{d}$, which are compatible with many similar measurements in adult mammals (Blaxter, 1972). In both these reports no mention was made of the strain of mice used and it is reasonable to presume that they were genetically-outbred mice. Brown et al. (1977) and Kownacki \& Keller (1978) also provided information on their control (unselected) or foundation stock. Both sets of measurements suggest that the growth 
of the foundation lines is as inefficient and the BMR is as high as the selected mice. It would appear therefore that the inbred strains from which the experimental animals had been selected possessed a trait associated with a low energetic efficiency of growth and that further selection on the basis of growth rate (both increased and decreased) has not altered the manifestation of this trait. Without further information it is impossible to say whether this is a common finding in inbred strains of mice or whether it is confined to CL (Brown et al. 1977) Q, (Falconer, 1973) or the unspecified strains used by Kownacki \& Keller (1978).

\section{Cell size and cell number}

The two strains showed similar patterns of development with respect to the changes in cell number (DNA per unit weight) and 'cell size' (protein per unit DNA) (Table 4). In both lines there was a marked increase in the value for protein:DNA before weaning indicating an increase in the 'cell size' rather than cell number during this phase of development i.e. a hypertrophic growth phase (Table 4) although there was some increase in the absolute amount of DNA in the preweaning period (Fig. 2(a)). After weaning the protein:DNA value changed much less (Table 4) but total DNA increased with body-weight (Table 3, Fig. 2(a)), indicating that cell numbers were increasing i.e. a hyperplastic growth phase. The pattern of growth observed here appears to be different from that reported by Winick \& Noble (1966) for the rat where preweaning growth is almost exclusively hyperplastic. Immediately after weaning the growth of the rat is a combination of hyperplasia and hypertrophy, gradually becoming exclusively hypertrophic until adult body size is attained.

Differences do exist be:ween QLF and QSC lines despite a similar over-all pattern of development. At birth and $19 \mathrm{~d}$ DNA: body-weight was lower and protein:DNA was higher in the QLF mice. Protein:DNA increased less between birth and $19 \mathrm{~d}$ in QLF mice compared to QSC with respect to the value at birth (QLF 3-8-fold, QSC 4-7-fold) indicating that an increase in cell numbers (rather than cell size) contributed more to over-all growth in the preweaning period. These results support the measurements of protein:DNA in a range of defined skeletal muscles from mice selected for rapid and slow rates of growth (Aberle \& Doolittle, 1976; Martin et al. 1979). There is contradictory evidence for an increase in cell size in QL mice reported by Falconer et al. (1978) where absolute cell mass was estimated in lung, liver, spleen, kidney and skeletal muscle and compared with an unselected control line. However this increase in cell size was not sufficient to account for the total increase in the weight of the organs examined and it was shown that the major contribution to increased weight was an increase in cell number.

RNA:DNA of the QLF mice was higher than that of the QSC at birth, 19 and $42 \mathrm{~d}$, indicating a higher RNA content per cell. An increase in RNA content per cell often is assumed to reflect a greater capacity of that cell for protein synthesis (Needham, 1964). However, total protein: total RNA was lower in the large strain mice at 19 and $42 \mathrm{~d}$ and was higher only at birth. There are many factors which can influence protein synthesis and the results available from this experiment do not permit speculation about alterations in protein metabolism betwe:en the two strains although Priestley \& Robertson (1973) failed to demonstrate differences in either protein synthesis or turnover between different lines of Q-strain mice using isolated ribosomes.

The Q-strain and other selected mice appear to be ideally suited to the study of changes in tissue components or metabolism brought about by selection for body size. Despite much endeavour by many workers, no major contributing factor to the cause of the increase in body size, apart from increased appetite, has yet come to light. The large animals do eat more but it is impossible to say if this is the cause or the effect of larger body size. In summary, the two strains of mice exhibit somewhat different patterns of development, but 
by maturity have a similar body composition. An increase in body size due to genetic selection may be due to a multiplicity of factors and it would appear that no one component of growth will suffer an easily detectable aberration from the normal.

The author would like to thank the staff of the Animal House, Foresterhill, Aberdeen for housing the animals. The assistance of Miss W. Henderson in the care and handling of the animals during feeding trials is much appreciated. The help and advice of Dr P. J. Reeds in the interpretation of some of the results is also acknowledged.

\section{REFERENCES}

Aberle, E. D. \& Doolittle, D. P. (1976). Growth 40, 133.

Atkinson, T., Fowler, V. R. F., Garton, G. A. \& Lough, A. K. (1972). Analyst, Lond. $97,562$.

Benedict, F. G. (1938). Vital Energetics. Washington, DC: Carnegie Institution of Washington.

Blaxter, K. L. (1972). In Festskrift til Knut Breirem p. 19 [L. S. Spildo, T. Homb and H. Hvidsten, editors]. Oslo: Mariendals Boktrykkeri A. S. Gjøvidk.

Brown, M. A. \& Frahm, R. R. (1975). J. Anim. Sci. 41, 1002.

Brown, M. A., Frahm, R. R. \& Johnson, R. R. (1977). J. Anim. Sci. 45, 19.

Davidson, J., Mathieson, J. \& Boyne, A. W. (1970). Analyst, Lond. 95, 181.

Eisen, E. J., Hayes, J. F., Allen, C. E., Bakker, H. \& Nagai, J. (1978). Growth $42,7$.

Ezekwe, M. O. \& Martin, R. J. (1975). Growth 39, 95.

Falconer, D. S. (1973). Genet. Res., Camb. 22, 291.

Falconer, D. S. (1977). Proc. Nutr. Soc. 36, 47.

Falconer, D. S., Gauld, I. K. \& Roberts, R. C. (1978). Genet. Res. Camb. 31, 287.

Firschein, H. E. \& Shill, J. P. (1966). Analyt. Biochem. 14, 296.

Hanrahan, J. P., Hooper, A. C. \& McCarthy, J. C. (1973). Anim. Prod. 16, 7.

Kielanowski, J. (1972). In Festskrift til Knut Breirem p. 111 [L. S. Spildo. T. Homb and H. Hvidsten, editors]. Oslo: Mariendals Boktrykkeri A. S. Gjovidk.

Kownacki, M. \& Keller, J. (1978). Genetica Polonica 19, 339.

Kownacki, M., Keller, J. \& Gebler, E. (1975). Genetica Polonica 16, 359.

Luff, A. R. \& Goldspink, G. (1967). Life Sci. 6, 1821.

Martin, R., White, J., Herbein, J. \& Ezekwe, M. O. (1979). Growth 43, 167.

Miller, D. S. \& Bender, A. E. (1955). Br. J. Nutr. 9, 382.

Munro, H. N. \& Fleck, A. (1969). In Mammalian Protein Metabolism pp. 423-525 [H. Munro, editor]. New York: Academic Press.

Needham, A. E. (1964). In The growth process in animals. London: Sir Isaac Pitman and Sons Ltd.

Priestley, G. C. \& Robertson, M. S. M. (1973). Genet. Res., Camb. 22, 255.

Pullar, J. D. \& Webster, A. J. F. (1977). Br. J. Nutr. 35, 355.

Reeds, P. J., Cadenhead, A., Fuller, M. F., Lobley, G. E. \& McDonald, J. D. (1980). Br. J. Nutr. 43, 445.

Robinson, D. W. \& Bradford, G. E. (1969). Growth 33, 221.

Rucklidge, G. J. \& McKenzie, J. D. (1980). Lab. Animals 14, 213.

Usinger, W. (1957). Arch. für Physiol. 265, 365.

Van der Wal, H., Verstegen, M. W. A. \& Van der Hel, W. (1976). In Energy Metabolism of Farm Animals, pp. 125-128 [M. Vermorel, editor]. Clermont Ferrand: G. de Bussac.

Winick, M. \& Noble, A. (1966). J. Nutr. 89, 300. 